\title{
Recombinant Yeast Technology at the Cutting Edge: Robust Tools for both Designed Catalysts and New Biologicals
}

\author{
Karin Kovar*, Verena Looser, Petr Hyka, Tobias Merseburger, and Christian Meier
}

\begin{abstract}
Health and safety concerns, enhanced quality criteria, and environmental sustainability, have prompted investigations into production using recombinant yeasts as a feasible alternative for isolation of proteins from natural animal or plant sources, as well as for processes utilising either mammalian cell cultures or bacterial systems. An overview of recent research papers and review articles provides readers with a comprehensive insight into the field of next-generation yeast expression systems. Major breakthroughs in recombinant yeast technology linked to Pichia pastoris are (i) the public availability of tools to generate proteins with tailored and highly homogenous $\mathrm{N}$-glycan structures, similar to the forms assembled in humans, (ii) the recent accomplishment of the annotation of its genome sequence, and finally, (iii) the presence of the first few (non-glycosylated) therapeutic proteins in Pichia on the market. The P. pastoris expression platform is now well developed, as proven by multiple products used in human and veterinary medicine and in industry (e.g. enzymes for chemical synthesis and for the modification/synthesis of pharmaceuticals, drug target proteins used for structural analysis or for high throughput screening, proteins for diagnostics, proteinous biomaterials, vaccines, and therapeutic proteins). Nevertheless, the complexity of protein analysis (monitoring) continues to restrict process development for recombinant products. Drawing on combined expertise in molecular biology and process technology, the Institute of Biotechnology (IBT) at the Zurich University of Applied Science (ZHAW) and its international partners have developed solutions which (i) fully eliminate (or partially reduce) the use of methanol, which is undesirable in high-cell-density and high-productivity processes, (ii) match both strain construction and process design with the target protein characteristics to the benefit of the cells' physiological shape, and (iii) allow multi-gene expressions to be balanced to achieve custom tailored and reproducible protein quality at the level of (engineered) posttranslational modifications. In addition to enabling superior product quality specifications to be achieved with reduced development time, these innovations have helped the industries involved to minimise financial risks and the risk of failure, as well as create an opportunity for (new) drugs with improved functionality at low cost.
\end{abstract}

Keywords: Green chemistry - Pichia pastoris expression platform · Recombinant enzymes . Tailored and engineered glycosylation · Therapeutic proteins

\section{Why Use Pichia for New Biologicals and Biocatalysts?}

Fundamental knowledge on next-generation yeast systems was gained primarily during the development of high-productivity bioprocesses for the manufacture of novel and/or improved protein drugs and follow-on products, in particular for high-value blockbusters like erythropoi-

\footnotetext{
${ }^{*}$ Correspondence: Prof. Dr. K. Kovar Institute of Biotechnology (IBT) School of Life Sciences and Facility Management (Department N)

Zurich University of Applied Sciences (ZHAW)

Grüental, Postfach 335

$\mathrm{CH}-8820$ Wädenswil

Tel. +41589345733

E-mail:koka@zhaw.ch
}

etin and various monoclonal antibody therapeutics (e.g. refs [1-9]). Yeasts combine the advantages of a eukaryotic expression system with those of a bacterial one. ${ }^{[10-12]}$ The facultative methanolutilising yeast Pichia pastoris, is now well developed as an expression platform and can be used to produce functional proteins which incorporate all the required posttranslational modifications (e.g. disulfide bonds, glycosylation) ${ }^{[13]}$ and which are secreted as the main soluble protein outside the cell into a simple mineral media at concentrations (titres) of several grams per liter (Table 1, Fig. 1 and 2). [14]

The properties of many proteins (e.g. folding, stability, trafficking, immunogenicity, and functionality) are strongly linked to the composition of the carbohydrate structures (glycans) attached to them. ${ }^{[33-35]}$ Similarly to the established mammalian cell lines, glyco-engineered Pichia cells yield glyco-patterns close to human ones but not completely identical. ${ }^{[4,5,19]}$ Moreover, the novel Pichia strains with eliminated yeastspecific and introduced heterologous genes (4 and as many as 14 respectively) allow glycosylation to be controlled and hence produce a more homogeneous product than the heterogeneous mixtures of glycoforms found naturally in mammals or the derived cell lines. ${ }^{[36]}$ Accordingly, the latest research results suggest Pichia yeast might be used in future instead of higher eukaryotes, ${ }^{[3]}$ such as insect and mammalian cell cultures, in the production of (human) proteins used for structural or pharmacological studies, diagnostics or therapy.

In turn the extensive research on biologicals has also enabled development of lower-value recombinant proteins/ enzymes for applications in preparative chemical synthesis (e.g. ref. [37]). Unlike the biologicals field with a few products, the chemistry market consists of a broad variety of products. To efficiently cope with this inherently broad product versatility, appropriate platform technologies utilising microorganisms 
Table 1. Highlighted features of Pichia technology

$\begin{array}{ll}\text { Features of } \text { Pichia technology } & \text { reference } \\ \text { - recombinant proteins with } \mathrm{N} \text {-glycosylation patterns similar to human } & {[4,15-19]} \\ \text { - secreted product as the main soluble protein in simple mineral media } & {[13,20]} \\ \text { - commercially available expression kits } & {[21,22]} \\ \text { - annotated genome sequence } & {[23-27]} \\ \text { - strong promoter (PAOX1) inducible by methanol } & {[13]} \\ \text { - synthetic promoters for fine tuned, both methanol-induced or methanol-free } & {[28]} \\ \text { gene expression } & {[29]} \\ \text { - high-throughput protocols for efficient clone screening } & {[30]} \\ \text { - more than } 10 \mathrm{~g} \text { liter }{ }^{-1} \text { of (soluble) protein } & {[31]} \\ \text { - rapid biomass growth up to cell densities of over } 200 \mathrm{~g} \mathrm{l}^{-1} & {[3]} \\ \text { - more than } 1 \mathrm{~g} \text { liter }{ }^{-1} \text { of monoclonal antibody with tailored, }>90 \% \text { uniform } & \\ \text { N-glycosylation in } 6-7 \text { days } & {[32]} \\ \text { - first Pichia product approved by FDA and several products in non-ICH markets } & \\ \text { aselected examples } & \end{array}$
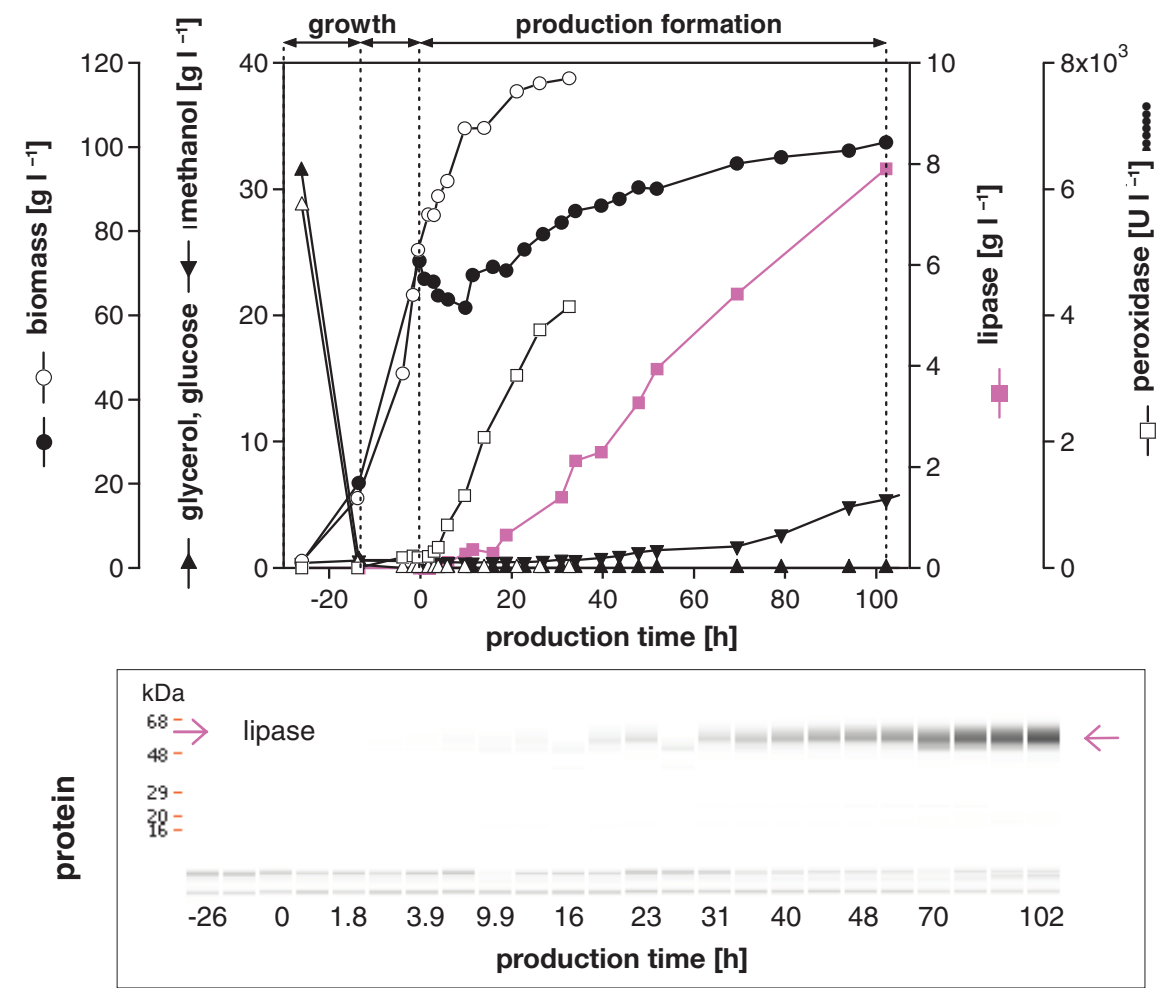

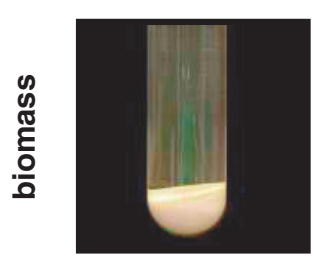

$20 \mathrm{~g} \mathrm{l}^{-1}$

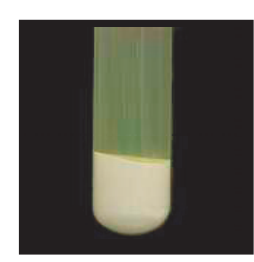

$73 \mathrm{~g} \mathrm{l}^{-1}$

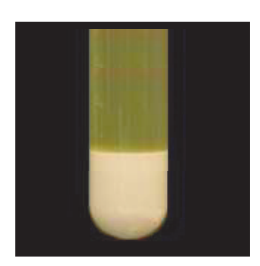

$101 \mathrm{~g} \mathrm{l}^{-1}$

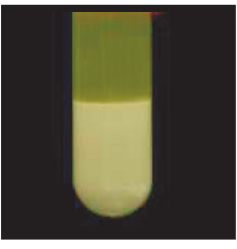

$\sim 160 \mathrm{~g} \mathrm{l}^{-1}$
Fig. 1. Biomass and product concentrations in high-productivity fedbatch culture. Top: The fedbatch processes comprise three phases divided by vertical dashed lines: (i) biomass growth in the batch started at $-26 \mathrm{~h}$ and (ii) fedbatch started at $-14 \mathrm{~h}$ and continued by (iii) a production phase in the fedbatch mode, which began at $0 \mathrm{~h}$. Two products and process strategies with $P$. pastoris are shown: (1) formation of horseradish peroxidase (after biomass growth with glucose) by reducing glucose addition to a low constant rate in a 14-litre bioreactor ${ }^{[28]}$ (open symbols) and (2) formation of lipase B from Candida antarctica (after biomass growth with glycerol) by exponential addition of methanol, in a 50-liter bioreactor (closed symbols). Middle: Data of protein analysis for the lipase process (LabChip 90, Caliper Life Sciences, Hopkinton MA, USA). Bottom: Samples after centrifugation for $5 \mathrm{~min}$ at 14,000 rpm to separate biomass and culture supernatant. were sought. ${ }^{[38,39]}$ Currently, P. pastoris represents a viable alternative to $E$. coli, $S$. cerevisiae or filamentous fungi primarily used in the manufacture of industrial enzymes or the biosynthesis of peptides. Within the global chemistry market, the proportion of products that were manufactured using biotechnological methods (biotransformation or in vivo biosynthesis), represented sales of US $\$ 50$ billion in 2008. The proportion of these products is expected to increase significantly to $20 \%$ of the total chemistry market in 2020, the total value of which is then predicted to be equivalent to sales of approximately US\$ 800 billion. ${ }^{[40]}$

Biotransformation, a method either using isolated enzymes or whole microbial cells to modify chemicals in reactions catalysed by specific enzymes, has been widely acknowledged as a feasible approach for achieving sustainable, 'green' chemistry as an established industrial practice. ${ }^{[41-44]}$ In addition to the superior conversion selectivity (including enantioselectivity), ${ }^{[45]}$ the specific benefits of biotransformation compared to conventional chemical synthesis are the practicability of the reaction occurring in just a few steps and its environmental suitability. Most of the biotransformation processes accomplished on an industrial scale with (whole) cells are still catalysed by the microorganisms from which the enzymes of interest originate. ${ }^{[38]}$ However, the demand is increasing for (i) improved biocatalysts suited to specific chemical reactions and physical conditions, ${ }^{[46-49]}$ and for (ii) pharma-grade enzymes of superior purity which are free of animalderived infectious agents unlike to those isolated from animal or plant materials. ${ }^{[50]}$ This trend is prompting the development of recombinant DNA technologies designed specifically for the economically attractive manufacture of biocatalysts. ${ }^{[37,38,50-52]}$

\section{One Goal - Plenty of Alternative Approaches}

The development of the Pichia expression system over the last 40 years, which has matured with the commercially available expression kits by Invitrogen, ${ }^{[53]}$ has been crucial for the wide-spread adoption of this system. ${ }^{[13,54,55]}$ The knowledge now available (as well as appropriate methods and tools), allows a choice to be made between several generic approaches which might accelerate the development of an appropriate process strategy. These approaches are applicable to particular product families, requiring only minimal specific adaptation on a protein-by-protein basis and, thus, without the need for entire de novo development. 


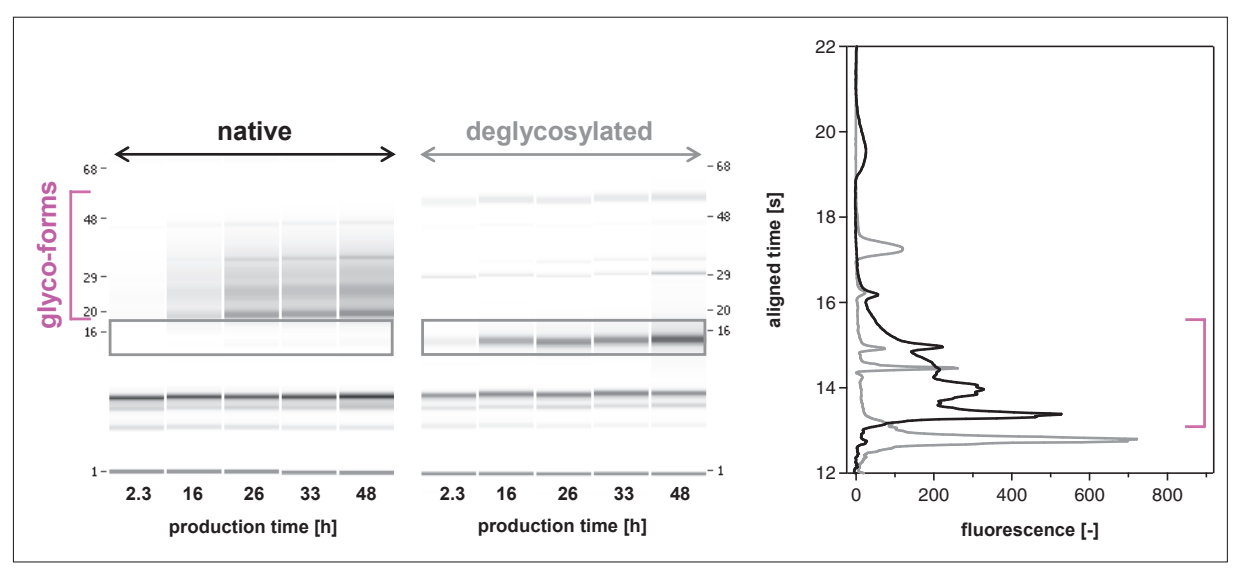

Fig. 2. Separation and identification of a glycosylated product. Samples from a high-cell-density fedbatch process containing glycosylated murine granulocyte-macrophage colony-stimulating factor (rmGM-CSF) were analysed by chip-based capillary gel-electrophoresis (LabChip 90, Caliper Life Sciences, Hopkinton MA, USA). The native samples of culture supernatant (i.e. nonpurified) were analysed directly and after deglycosylation by $24 \mathrm{~h}$ at $37^{\circ} \mathrm{C}$ treatment with endoglycosidase $\mathrm{H}$ (Endo H, EC 3.2.1.96, $29 \mathrm{kDa}$ ). The data are presented in gel-like format (left) and as an electropherogram of the sample taken at $16 \mathrm{~h}$ of production time (right).

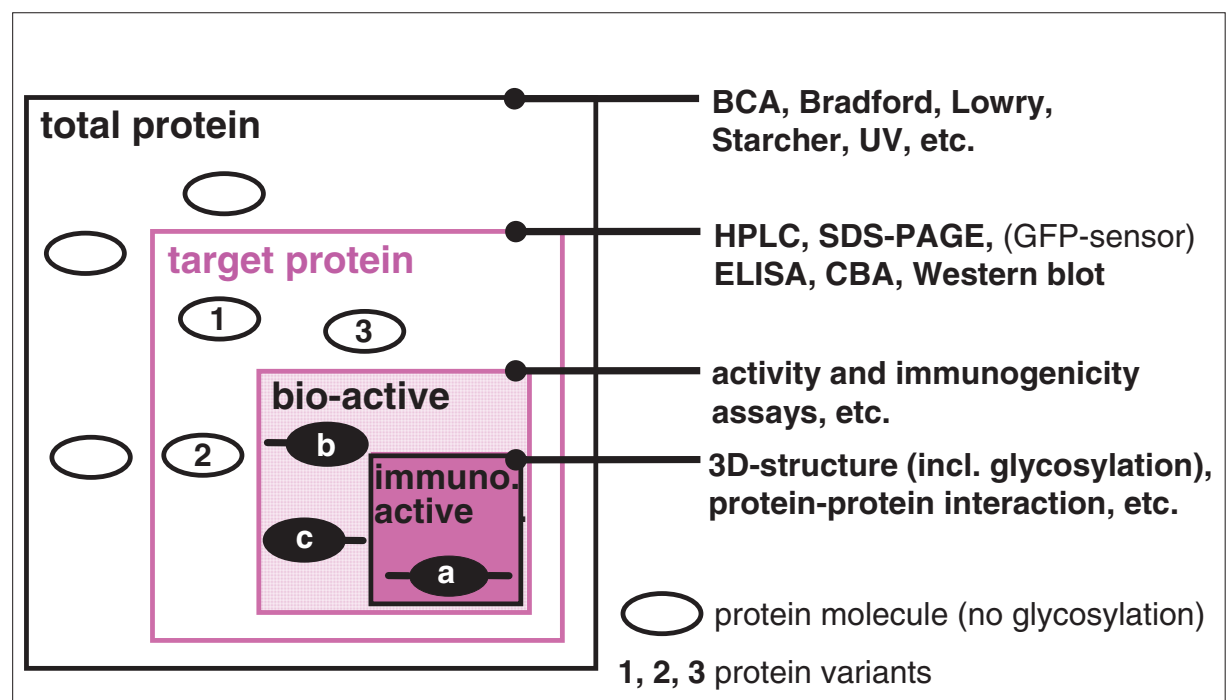

a, b, c biological function - glyco-sites

Fig. 3. Possible approaches for product identification and quantification. The extent of the analysis of a proteinous product is determined by the (research) question that needs to be answered and can vary from a cursory analysis to analyses confirming specific activity and structure. (All abbreviations are explained in the Nomenclature section.)

\subsection{You Get what you Screen for}

The Pichia system has benefited from molecular genetic tools, which were primarily developed for $S$. cerevisiae, including the alpha-mating factor secretion signal. The technology of homologous recombination, commonly used with Pichia for heterologous gene expression, ${ }^{[29]}$ results in multiple clones which vary in expression/production properties. Accordingly, the appropriateness and efficiency of the applied screening method determines the success of the selection of those few clones which most efficiently produce the target protein (Fig. 3[29]). The laborious screening of thousands of clones becomes even more complex when desired posttranslational modifications are targeted, which result from multi-gene expression (e.g. glycosylation, 3D-protein structure).[6] Currently, several specialised service providers have established high-throughput technologies that enable the best-performing strains to be selected from micro- to bioreactorscales (e.g. ref. [29]). The engineering of new protein sequences by mutagenesis and subsequent screening is still less time consuming in prokaryotic systems due to the ease of transformation of the plasmid into the cytoplasm of the cell. Nevertheless, advanced cloning procedures and vectors for Pichia are steadily improving and reducing the workload. ${ }^{[56]}$

\subsection{Moving beyond Standard Cultivation Protocols}

Commercially available expression kits (i.e. from Invitrogen ${ }^{[53]}$ and the Glyco Switch technology[15]), provide scientists with many necessary tools and ready-touse recipes (i.e. including media compositions, process control strategies, etc.) to produce heterologous proteins with $P$. pastoris (e.g. ref. [57]). However, the users might mistakenly be led to believe that cloning and producing proteins with Pichia at any scale is guaranteed to be a success.

When developing recombinant products, it is common practice to carry out strain construction before making any decisions concerning cultivation in a bioreactor or downstream processing. Thus, any problems arising during process development are often solved by technological (bioprocessing) means rather than by revising the strategy for strain design and/ or host selection.

Generally, classical cultivation and downstream techniques apply for Pichia protein production and purification. ${ }^{[58]}$ The typical cultivation process (Fig. 1) is based on a three-stage culture with a batch and subsequent fedbatch phases with glycerol for biomass growth followed by a production phase in fedbatch mode with methanol. The advantages of the strong and tightly regulated PAOX1 promoter, which have resulted in the wide application of the Pichia system in academic research laboratories, have also proven to be a major obstacle to its implementation at industrial scale. The high demand for oxygen and the associated heat evolution, in addition to the potential flammability and explosiveness of the methanol used to induce the PAOX1, pose solvable challenges to process development at large scale with high-cell-density cultures. ${ }^{[58,59]}$ In principle, the obstacles related to the use of methanol can be overcome by replacing a portion of the undesired methanol with a complementary substrate (i.e. glucose, glycerol, sorbitol), ${ }^{[60-65]}$ by using a different type of promoter (Table 2) or by bioreactor improvements. However, numerous manufacturers of industrial proteins have successfully implemented Pichia processes with methanol culture columns higher than $10 \mathrm{~m}^{3}{ }^{3}{ }^{[73]}$ Although, the constitutive PGAP promoter is used with glucose (methanolfree), ${ }^{[69,74]}$ such a constitutive expression is not suited to toxic proteins that impair the cells' physiology. Therefore, the synthetic promoters (Table 2, Fig. 1), which have recently become available, ${ }^{[28]}$ combining the advantages of inducible product formation and methanol-free cultivation with glycerol (or glucose), promise to facilitate the industrial implementation of Pichia processes.

Cell physiology, influenced by molecular design of the strain and the growth and cultivation conditions, has been crucial for 
Table 2. Comparison of promoters used for production of heterologous proteins in P. pastoris in carbon-limited cultures with continuous addition of a substrate.

The research groups which first introduced the particular promoters are included as references. (All abbreviations are explained in the Nomenclature section.)

$\begin{array}{lllll}\begin{array}{l}\text { promoter } \\ \text { PAOX1 }\end{array} & \begin{array}{l}\text { substrate } \\ \text { methanol }\end{array} & \begin{array}{l}\text { expression } \\ \text { inducible }\end{array} & \begin{array}{l}\text { induction } \\ \text { carbon source (methanol) }\end{array} & \begin{array}{l}\text { researcher/reference } \\ {[66-68]}\end{array} \\ \text { synthetic } & \begin{array}{l}\text { glycerol }^{\text {b }} \\ \text { (or glucose) }^{\text {inducible }}\end{array} & \begin{array}{l}\text { carbon flux } \\ \text { 'derepression' }\end{array} & {[28]} \\ \text { PGAP } & \begin{array}{l}\text { glucose }^{\text {c }} \\ \text { (or glycerol) }\end{array} & \text { constitutive }^{\text {d }} & \text { none } & \text { [69] }\end{array}$

aaddition of methanol is essential for product formation, but the latter continues unaffected even when $>60 \%$ of methanol is replaced with another carbon substrate; ${ }^{[62,70-72] ~ b r e g u l a t i o n ~ i s ~}$ based on a repression-derepression principle with glucose or glycerol as the only substrates utilised; ${ }^{[28]}$ promoter activity in cells grown with glycerol or methanol is approximately $60 \%$ and $30 \%$ respectively of the level observed for glucose; ${ }^{[69]} \mathrm{d} g e n e$ expression levels and product formation are uncontrollable.

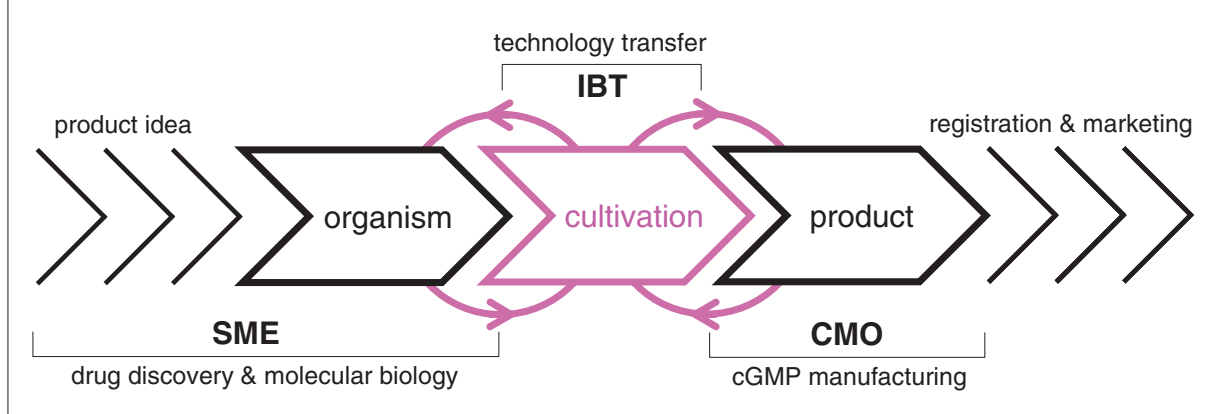

Fig. 4. Reinforced modes of collaboration in process development. By providing an effective interface between product developers and (custom) manufacturers, the Institute of Biotechnology at ZHAW facilitates the transfer of information and technology. The benefit of such an approach, as illustrated in this schema, is that the detailed physiology and process knowledge can be introduced at an early stage of development of the recombinant strain, and the technology developed can be efficiently transferred to the contract manufacturer. (All abbreviations are explained in the Nomenclature section.)

achieving both the desired product quantity and quality. ${ }^{[58,75,76]}$ For example, impaired cell vitality has been observed to be the result of the combined effects of production of recombinant protein, low $\mathrm{pH}$, and high-cell-density. ${ }^{[72]}$ Low $\mathrm{pH}$ values $(\leq 4)$ are commonly applied to counteract proteolysis. ${ }^{[13,77]}$ Many attempts at quantitative assessment of the physiology of individual cells have been made in recent bioprocess developments. ${ }^{[72,78-80]}$ However, only by knowing the number of (vital) cells that express the target molecule at the highest possible rate, can the number of these cells within the entire population be maximized and the proportion of dead cells undergoing lysis be kept to a minimum. Hence, the common concept that extracellular methanol concentration is the main, crucial factor for toxicity and impaired cell physiology during methanol induced protein production is questioned. ${ }^{[72,81]} \mathrm{In}$ fact, previous exposure of the cell to methanol, ${ }^{[62]}$ or the exposure time combined with other environmental conditions has a more significant effect on cell physiology than the characteristics of the target protein has the potential to significantly enhance bioprocess performance, robustness and reproducibility, ${ }^{[72]}$ in terms of scalable titres, gram per litre and hour productivity, and tailored product quality. The greatest benefit from using Pichia is achieved when it is, as is typical, utilised to secrete a correctly folded protein into chemically defined media free of other proteins (Fig. 2). Moreover, in the case of glycoproteins made by glycolengineered Pichia, highly homogenous glycosylation patterns are achieved. Thus, the $P$. pastoris yeast is an emerging, preferred expression and production system to both facilitate and simplify the target protein capture within its purification (e.g. refs $[90,91])$.

The complexity of protein analysis (and monitoring), however, continues to restrict process development for recombinant products (Fig. 3). The availability of reliable, quick and affordable quantification methods for determination of the functional form, as well as that of all the undesired variants of complex proteinous products, is of crucial relevance in the rational development and optimisation of both the molecular design of the strain and the cultivation process. Such methods permit the concentrations of several product variants to be determined at various time points within a process. This information, when combined with the kinetics and stoichiometry of product formation, can be used to assess how the physiological state of Pichia is affected by culture conditions. ${ }^{[72,76]}$

The expertise available from the IBT at ZHAW creates an effective bridge (as illustrated in Fig. 4) between product developers from SMEs or university institutions and product manufacturers (CMOs) by identifying the essential properties of newly developed strains in real production processes. Thus, relevant information can be provided to the developers in a timely manner. The strain developers benefit through simultaneously (i) acquiring a deeper insight into strain behaviour at production scale and (ii) utilising the information immediately in their ongoing development programmes. IBT effectively facilitates the transfer of the optimised production process technology to large-scale producers (CMOs). Such cooperation provides considerable strategic advantages to SMEs in terms of the reduction of total development costs, accelerated product development, and the elimination of mistakes in the early phases of product development and costly engineering adjustments, which can occur in the later stages of development. 


\section{Conclusions and Outlook}

The beneficial features of the Pichia system hold the promise of further success for this microbial host, beyond the first products that have recently been approved by the regulatory authorities (e.g. refs $[32,92,93])$, allowing large-scale biotechnological production at acceptable costs. The main features of the next-generation Pichia system are summarised in Table 1. In particular, the following factors will act as triggers and drivers in establishing nextgeneration yeast systems (including Pichia) in biotechnological manufacturing:

(i) due to successful engineering of the $\mathrm{N}$-glycan pathway, novel pharmacological properties can be introduced (e.g. ref. [18]);

(ii) several patents for blockbuster drugs, produced at high cost using mammalian cells, have recently expired, or are soon to expire (e.g. erythropoietin, EPO), ${ }^{[4]}$ thus, paving the way for follow-on biologicals;

(iii) particular proteins/peptides are extremely difficult to produce in established systems, thus alternatives are being sought (e.g. ref. [44]);

(iv) continuing demand for chiral building blocks and enantiomerically pure compounds increases the demand for the (designed) biocatalysts used in their manufacture; [44]

(v) to efficiently perform complex biochemical reactions whole-cell biocatalysis with tailored recombinant organisms is favoured; [38,47]

(vi) amassing innovative intellectual property is expected to be coupled with considerable, new royalty revenues; and

(vii) current US and European government policy is forcing a reduction in costs in their health systems, while simultaneously allowing access to new medicines for patients and maintaining the safety of new products.

\section{Acknowledgement}

Drawing on ZHAW's over 15 years of experience in studying Pichia physiology, the long-term challenges of establishing Pichia platform technology have been jointly addressed with many international academic and industry partners, as well as in Biotechnet Switzerland projects. The work on high-celldensity cultivations at the ZHAW has been partially supported by the Swiss Agency for Technology and Innovation (i.e. CTI in the scope of Eureka project E!3415) and the Swiss Academy of Engineering Sciences (SATW). Our work would never have reached such maturity without the generous support of renowned groups active in the field of Pichia's molecular biology, in particular, Anton Glieder (ACIB, Graz/Vienna, Austria) and Nico Callewaert (VIB, Ghent, Belgium). The authors especially appreciate both the critical review of this paper, as well as help in highlighting the future needs of the industry provided by (given in alphabetic order): Dave Bramhill (RCT, Tuscon, USA), Hans-Peter Meyer (Lonza), Thomas Purkarthofer and Roland Weis (VTU Technology, Grambach, Austria), and Roland Wohlgemuth (Sigma Aldrich). Finally, the qualified help of Stella Cook and Darren Mace in proofreading and editing the manuscript is greatly appreciated.

\section{Nomenclature}

BCA bicinchoninic acid assay

CBA cytometric bead array

CDW cell dry weight

cGMP current good manufacturing practice

CMO contract manufacturing organisation

ELISA enzyme-linked immunosorbent assay

GFP green fluorescent protein

HPLC high-performance liquid

chromatography

IBT Institute of Biotechnology

$\mathrm{ICH}$ International Conference on

Harmonisation

PAOX1 promoter alcohol oxidase

PGAP promoter glyceraldehyde

3-phosphate dehydrogenase

SDS-PAGE sodium dodecyl sulfate polyacrylamide gel electrophoresis

SME small and medium sized enterprise

UV ultraviolet light

ZHAW Zurich University of Applied Sciences

Received: September 6, 2010

[1] T. U. Gerngross, Nat. Biotechnol. 2004, 22, 1409

[2] K. Kobayashi, S. Kuwae, T. Ohya, T. Ohda, M. Ohyama, K. Tomomitsu, J. Biosci. Bioeng. 2000, 90, 280.

[3] T. I. Potgieter, M. Cukan, J. E. Drummond, N. R. Houston-Cummings, Y. Jiang, F. Li, H. Lynaugh, M. Mallem, T. W. McKelvey, T. Mitchell, A. Nylen, A. Rittenhour, T. A. Stadheim, D. Zha, M. d'Anjou, J. Biotechnol. 2009, 139, 318 .

[4] S. R. Hamilton, R. C. Davidson, N. Sethuraman, J. H. Nett, Y. W. Jiang, S. Rios, P. Bobrowicz, T. A. Stadheim, H. J. Li, B. K. Choi, D. Hopkins, H. Wischnewski, J. Roser, T. Mitchell, R. R. Strawbridge, J. Hoopes, S. Wildt, T. U. Gerngross, Science 2006, 313, 1441.

[5] S. R. Hamilton, P. Bobrowicz, B. Bobrowicz, R. C. Davidson, H. Li, T. Mitchell, J. H. Nett, S. Rausch, T. A. Stadheim, H. Wischnewski, S. Wildt, T. U. Gerngross, Science 2003, 301, 1244

[6] A. Beck, T. Wurch, C. Bailly, N. Corvaia, Nat. Rev. Immunol. 2010, 10, 345 .

[7] J. R. Birch, A. J. Racher, Adv. Drug Delivery Rev. 2006, 58,671

[8] P. Umana, J. Jean-Mairet, R. Moudry, H. Amstutz, J. E. Bailey, Nat. Biotechnol. 1999, 17,176

[9] Y. Kaneko, F. Nimmerjahn, E. V. Ravetch, Science 2006, 313, 670.

[10] K. Kovar, H. P. Meyer, Chimia 2005, 59, 723.

[11] R. Wohlgemuth, N. Biotechnol. 2009, 25, 204.

[12] A. Graf, M. Dragosits, B. Gasser, D. Mattanovich, FEMS Yeast Res. 2009, 9, 335.
[13] J. M. Cregg, J. L. Cereghino, J. Shi, D. R Higgins, Mol. Biotechnol. 2000, 16, 23.

[14] http://www.vtu.com/en/1870/Protein-Techno$\log y$.

[15] P. Jacobs, S. Geysens, W. Vervecken, R Contreras, N. Callewaert, Nat. Protoc. 2009, 4, 58.

[16] W. Vervecken, V. Kaigorodov, N. Callewaert, S. Geysens, K. De Vusser, R. Contreras, Appl. Environ. Microbiol. 2004, 70, 2639.

[17] W. Vervecken, N. Callewaert, V. Kaigorodov, S. Geysens, R. Contreras, Methods Mol. Biol. 2007, 389, 119.

[18] A. Beck, O. Cochet, T. Wurch, Expert Opin Drug Dis. 2010, 5, 95.

[19] S. Wildt, T. U. Gerngross, Nat. Rev. Microbiol. $2005,3,119$.

[20] G. P. Cereghino, J. L. Cereghino, C. Ilgen, J. M. Cregg, Curr. Opin. Biotechnol. 2002, 13, 329.

[21] Invitrogen, Catalog No. K1719-91 2002, Version B 053002.

[22] B. Tolner, L. Smith, R. H. Begent, K. A. Chester, Nat. Protoc. 2006, 1, 1006.

[23] http://www.pichiagenome.org.

[24] K. De Schutter, Y. C. Lin, P. Tiels, A. Van Hecke, S. Glinka, J. Weber-Lehmann, P. Rouze, Y. Van de Peer, N. Callewaert, Nat. Biotechnol. 2009, 27, 561.

[25] D. Mattanovich, A. Graf, J. Stadlmann, M Dragosits, A. Redl, M. Maurer, M. Kleinheinz, M. Sauer, F. Altmann, B. Gasser, Microb. Cell Fact. 2009, 8, 29.

[26] D. Mattanovich, N. Callewaert, P. Rouze, Y. C. Lin, A. Graf, A. Redl, P. Tiels, B. Gasser, K. De Schutter, Microb. Cell Fact. 2009, 8, 53.

[27] http://bioinformatics.psb.ugent.be/genomes/ view/Pichia-pastoris.

[28] F. S. Hartner, C. Ruth, D. Langenegger, S. N Johnson, P. Hyka, G. P. Lin-Cereghino, J. LinCereghino, K. Kovar, J. M. Cregg, A. Glieder, Nucleic Acids Res. 2008, 36, e76.

[29] R. Weis, R. Luiten, W. Skranc, H. Schwab, M Wubbolts, A. Glieder, FEMS Yeast Res. 2004, 5 , 179

[30] J. J. Clare, F. B. Rayment, S. P. Ballantine, K. Sreekrishna, M. A. Romanos, Bio-Technology 1991, 9, 455.

[31] J. Heyland, J. Fu, L. M. Blank, A. Schmid, Biotechnol. Bioeng. 2010, 107, 357.

[32] http://www.rctech.com.

[33] R. Jefferis, Nat. Rev. Drug Discov. 2009, 8, 226

[34] C. K. Schneider, M. Papaluca, P. Kurki, Nat. Biotechnol. 2009, 27, 507.

[35] G. Walsh, R. Jefferis, Nat. Biotechnol. 2006, 24 , 1241.

[36] K. De Pourcq, K. De Schutter, N. Callewaert, Appl. Microbiol. Biotechnol. 2010, 87, 1617.

[37] S. Abad, J. Nahalka, G. Bergler, S. A. Arnold, R. Speight, I. Fotheringham, B. Nidetzky, A. Glieder, Microb. Cell Fact. 2010, 9, 24.

[38] B. Pscheidt, A. Glieder, Microb. Cell Fact. 2008, 7, 25.

[39] T. Drepper, T. Eggert, W. Hummel, C. Leggewie, M. Pohl, F. Rosenau, S. Wilhelm, K. E. Jaeger, Biotechnol. J. 2006, 1, 777 .

[40] H. P. Meyer, N. J. Turner, Mini-Rev. Org. Chem 2009, 6, 300

[41] N. Anastas, J. Warner, Chem. Res. Toxicol. 2004, 17, 1765

[42] A. Schmid, J. S. Dordick, B. Hauer, A. Kiener, M. Wubbolts, B. Witholt, Nature 2001, 409.

[43] N. M. Shaw, K. T. Robins, A. Kiener, $A d v$. Synth. Catal. 2003, 345, 425.

[44] O. Ghisalba, H. P. Meyer, R. Wohlgemuth, B in 'Encyclopedia of Industrial Biotechnology: Bioprocess, and Cell Technology', Ed. M. C. Flickinger, Wiley \& Sons, Inc., 2010.

[45] R. Wohlgemuth, Curr. Opin. Microbiol. 2010 , 13,283 .

[46] M. Konarzycka-Bessler, K. E. Jaeger, Trends Biotechnol. 2006, 24, 248. 
[47] K. Schroer, K. Peter Luef, F. Stefan Hartner, A. Glieder, B. Pscheidt, Metab. Eng. 2010, 12, 8.

[48] G. D. Su, D. F. Huang, S. Y. Han, S. P. Zheng, Y. Lin, Appl. Microbiol. Biotechnol. 2010, 86 , 1493.

[49] S. Tamalampudi, M. D. M. R. Talukder, S. Hama, T. Tanino, Y. Suzuki, A. Kondo, H. Fukuda, Appl. Microbiol. Biotechnol. 2007, 75, 387.

[50] A. L. Demain, P. Vaishnav, Biotechnol. Adv. 2009, 27, 297.

[51] A. Glieder, R. Weis, W. Skranc, P. Poechlauer, I. Dreveny, S. Majer, M. Wubbolts, H. Schwab, K. Gruber, Angew. Chem. Int. Ed. 2003, 42, 4815.

[52] S. Das, J. H. Glenn, M. Subramanian, Biotechnol. Prog. 2010, 26, 607.

[53] http://products.invitrogen.com/ivgn/product/ A11151.

[54] http://www.kgi.edu/x753.xml.

[55] http://www.pichia.com/pichia_system.pdf.

[56] L. Fernandez, N. Jiao, P. Soni, Y. Gumulya, L. G. De Oliveira, M. T. Reetz, Biocatal. Biotransform. 2010, 28, 122.

[57] http://www.kgi.edu/x6712.xml.

[58] S. Curvers, P. Brixius, T. Klauser, J. Thommes, D. Weuster-Botz, R. Takors, C. Wandrey, Biotechnol. Prog. 2001, 17, 495.

[59] J. Stratton, V. Chiruvolu, M. Meagher, Methods Mol. Biol. 1998, 103, 107.

[60] E. Celik, P. Calik, S. G. Oliver, Biotechnol. Bioeng. 2010, 105, 317.

[61] 'Biopharmaceuticals: why use yeasts?' Conference Proceedings of the Biotech 2008 and 4th Swiss-Czech Symposium, Eds. K. Kovar, R. Strnadová, C. Meier, B. M. Lussi Bell, 2008, Inst. of Biotechnology, ZHAW, ISBN 978-3905745-14-6.

[62] C. Jungo, I. Marison, U. von Stockar, J. Biotechnol. 2007, 130, 236

[63] C. Jungo, I. Marison, U. von Stockar, J. Biotechnol. 2007, 128, 824.

[64] C. Jungo, J. Schenk, M. Pasquier, I. W. Marison, U. von Stockar, J. Biotechnol. 2007, 131, 57.

[65] A. Sola, P. Jouhten, H. Maaheimo, F. SanchezFerrando, T. Szyperski, P. Ferrer, Microbiology 2007, 153, 281.

[66] J. F. Tschopp, P. F. Brust, J. M. Cregg, C. A. Stillman, T. R. Gingeras, Nucleic Acids Res. 1987, 15, 3859.
[67] J. M. Cregg, J. F. Tschopp, C. Stillman, R Siegel, M. Akong, W. S. Craig, R. G. Buckholz, K. R. Madden, P. A. Kellaris, G. R. Davis, B. L. Smiley, J. Cruze, R. Torregrossa, G. Velicelebi, G. P. Thill, Bio/Technology 1987, 5, 479.

[68] S. B. Ellis, P. F. Brust, P. J. Koutz, A. F. Waters, M. M. Harpold, T. R. Gingeras, Mol Cell Biol. 1985, 5 .

[69] H. R. Waterham, M. E. Digan, P. J. Koutz, S. V. Lair, J. M. Cregg, Gene 1997, 186.

[70] R. A. Brierley, R. S. Siegel, C. M. Bussineau, W. S. Craig, G. C. Holtz, G. R. Davis, R. G. Buckholz, G. P. Thill, L. M. Wondrack, M. E. Digan, M. M. Harpold, S. V. Lair, S. B. Ellis, M. E. Williams, 1990, WO9003431.

[71] T. Egli, O. Kappeli, A. Fiechter, Arch. Microbiol. 1982, 131, 1.

[72] P. Hyka, T. Zullig, C. Ruth, V. Looser, C. Meier, J. Klein, K. Melzoch, H. P. Meyer, A. Glieder, K Kovar, Appl. Environ. Microbiol. 2010, 76, 4486.

[73] http://www.biocon.com/biocon_manufacture_ micro.asp.

[74] A. L. Zhang, J. X. Luo, T. Y. Zhang, Y. W. Pan, Y. H. Tan, C. Y. Fu, F. Z. Tu, Mol. Biol. Rep. 2009, 36, 1611.

[75] J. Schenk, K. Balazs, C. Jungo, J. Urfer, C. Wegmann, A. Zocchi, I. W. Marison, U. von Stockar, Biotechnol. Bioeng. 2008, 99, 368.

[76] B. Gasser, M. Saloheimo, U. Rinas, M. Dragosits, E. Rodriguez-Carmona, K. Baumann, M. Giuliani, E. Parrilli, P. Branduardi, C. Lang, D. Porro, P. Ferrer, M. L. Tutino, D. Mattanovich, A. Villaverde, Microb. Cell Fact. 2008, 7, 11 .

[77] M. Jahic, A. Veide, T. Charoenrat, T. Teeri, S. O Enfors, Biotechnol. Prog. 2006, 22, 1465.

[78] T. Charoenrat, M. Ketudat-Cairns, H. StendahlAndersen, M. Jahic, S. O. Enfors, Bioproc. Biosyst. Eng. 2005, 27, 399.

[79] F. Hong, N. Q. Meinander, L. J. Jonsson, Biotechnol. Bioeng. 2002, 79, 438.

[80] X. Shi, T. Karkut, M. Chamankhah, M. AltingMees, S. M. Hemmingsen, D. Hegedus, Protein Expression Purif. 2003, 28, 321.

[81] W. Zhang, M. A. Bevins, B. A. Plantz, L. A. Smith, M. M. Meagher, Biotechnol. Bioeng. 2000, 70, 1 .

[82] M. C. d'Anjou, A. J. Daugulis, Biotechnol. Lett. 2000, 22,341 .
[83] M. M. Guarna, G. J. Lesnicki, B. M. Tam, J. Robinson, C. Z. Radziminski, D. Hasenwinkle, A. Boraston, E. Jervis, R. T. Macgillivray, R. F. Turner, D. G. Kilburn, Biotechnol. Bioeng. 1997, 56, 249.

[84] S. Hellwig, F. Emde, N. P. G. Raven, M. Henke, P. van der Logt, R. Fischer, Biotechnol. Bioeng. 2001, 74, 344.

[85] J. A. Serrato, V. Hernandez, S. EstradaMondaca, L. A. Palomares, O. T. Ramirez, Biotechnol. Appl. Biochem. 2007, 47, 113.

[86] M. Dragosits, J. Stadlmann, J. Albiol, K Baumann, M. Maurer, B. Gasser, M. Sauer, F. Altmann, P. Ferrer, D. Mattanovich, J. Proteome Res. 2009, 8, 1380.

[87] R. G. Werner, K. Kopp, M. Schlueter, Acta Paediatr. 2007, 96, 17.

[88] H. J. Li, N. Sethuraman, T. A. Stadheim, D. X Zha, B. Prinz, N. Ballew, P. Bobrowicz, B. K. Choi, W. J. Cook, M. Cukan, N. R. HoustonCummings, R. Davidson, B. Gong, S. R. Hamilton, J. P. Hoopes, Y. W. Jiang, N. Kim, R. Mansfield, J. H. Nett, S. Rios, R. Strawbridge, S. Wildt, T. U. Gerngross, Nat. Biotechnol. 2006, 24, 210.

[89] E. Kainz, A. Gallmetzer, C. Hatzl, J. H. Nett, H. Li, T. Schinko, R. Pachlinger, H. Berger, Y. Reyes-Dominguez, A. Bernreiter, T. Gerngross, S. Wildt, J. Strauss, Appl. Environ. Microbiol. 2008, 74, 1076 .

[90] H. P. Meyer, J. Brass, C. Jungo, J. Klein, J. Wenger, R. Mommers, BioProcess International 2008, $6,10$.

[91] N. Ferrer-Miralles, J. Domingo-Espin, J. L. Corchero, E. Vazquez, A. Villaverde, Microb. Cell Fact. 2009, 8.

[92] http://pichia.com.

[93] http://en.wikipedia.org/wiki/Pichia_pastoris. 